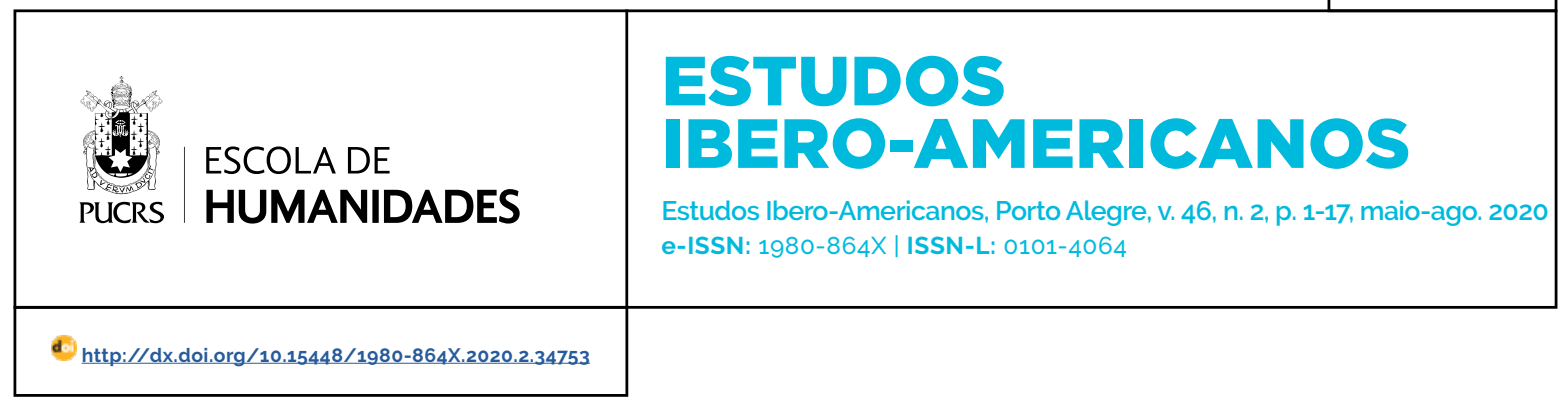

\title{
The Lisbon International Congress of the Press: the dawn of professional journalism
}

\author{
O Congresso Internacional da Imprensa de Lisboa: a alvorada do jornalismo profissional \\ El Congresso Internacional de la Prensa de Lisboa: Los albores del periodismo profissional
}

Adelaide Maria Muralha Vieira Machado ${ }^{1}$ orcid.org/0000-0003-3702-0569 adelaidemachado@sapo.pt

Recebido em: 11 jul. 2019. Aprovado em: 4 abr. 2020. Publicado em: 25 ago. 2020.

\section{(c) (1)}

Artigo está licenciado sob forma de uma licença Creative Commons Atribuição 4.0 Internacional.
Abstract: This is a study of cultural history that intends to analyse the importance of the international gatherings for the history of the press and journalism. The congresses and their theoretical work provided an important contribution to the exposure and the deepening of those issues that, in the Lisbon Congress, led to the approval of a directive by which each national association should promote journalism within higher education. Centred in this event demonstrates how, without losing completely the sense of mission, journalism became a regulated profession and the journalist a professional with rights and duties inherent in that condition. In connection, the beginnings of the press as mega-industry and the position of the journalist as an employee in the cultural and political global context, with all the class associations, the alliances and social cleavages that this growth caused along the $20^{\text {th }}$ century were patent in the debate occurred in Lisbon, substantiating it in a particularly decisive period of the evolution of democratic society. As a symptom of growth and adaptation, the debate during the Congress crisscrossed several important positions regarding the evolution of journalism, both as an idea and a concept, and as a profession. In addition to being a contribution to the research of the history of the press and its main actors in a little-studied chapter the international relations of the press, the relevance of this study lies in the fact of opening for current debates and reflection helping to understand the failures and achievements of contemporaneity.

Key words: History of the Press, Cultural History, Journalism, Journalists, Press Associations, Democracy, $20^{\text {th }}$ Century

Resumo: Este é um estudo da história cultural que pretende analisar a importância dos encontros internacionais para a história da imprensa e do jornalismo. Os congressos internacionais e o seu trabalho teórico deram um importante contributo para a exposição e o aprofundamento das questões que, no Congresso de Lisboa, levaram à aprovação de uma diretiva através da qual cada associação nacional deveria promover jornalismo dentro do ensino superior. Centrado nesse evento demonstra-se como, sem perder completamente o sentido de missão, o jornalismo se tornou numa profissão regulamentada, e o jornalista um profissional com direitos e deveres inerentes a essa condição. Em conexão, os primórdios da imprensa como mega-indústria e a posição do jornalista como colaborador no contexto cultural e político global, com todas as associações de classes, as alianças e clivagens sociais que este crescimento provocou ao longo do dia 20 século, foram patenteadas no debate de Lisboa que fundamenta um periodo particularmente decisivo na evolução da sociedade democrática. Como sintoma de crescimento e adaptação, o debate durante o Congresso cruzou várias posições importantes em relação à evolução do jornalismo, como ideia e conceito, tal como profissão. Para além de ser um contributo para a investigação da história da imprensa e dos seus agentes principais, num capítulo pouco estudado das relações internacionais da imprensa, a relevância deste estudo reside no fato de abrir para os debates e a reflexão atuais ajudando na compreensão das falhas e realizações da contemporaneidade.

Palavras chave: História da Imprensa, História Cultural, Jornalismo, Jornalistas, Associações de Imprensa, Congressos Internacionais de Imprensa, Democracia, Século 20 
Resumen: Se trata de un estudio de la historia cultural que pretende analizar la importancia de los encuentros internacionales para la historia de la prensa y el periodismo. Los congresos y su trabajo teórico proporcionaron una importante contribución a la exposición y a la profundización de las cuestiones que en el Congreso de Lisboa llevaron a la aprobación de una directiva por la que cada asociación nacional debería promover el periodismo dentro de la educación superior. Centrado en este evento demuestra cómo, sin perder por completo el sentido de la misión, el periodismo se convirtió en una profesión regulada y el periodista un profesional con derechos y deberes inherentes a esa condición. En relación con los inicios de la prensa como mega industria y la posición del periodista como empleado en el contexto cultural y político global, con todas las asociaciones de clase, las alianzas y las divisiones sociales que este crecimiento causó a lo largo del siglo XX siglo fueron patentes en el debate ocurrido en Lisboa, que lo corroboran en un periodo particularmente decisivo de la evolución de la sociedad democrática. Como sintoma de crecimiento y adaptación, el debate durante el Congreso atravesó varias posiciones importantes sobre la evolución del periodismo, como idea y concepto, tal como profesión. Además de ser una contribución a la investigación de la historia de la prensa y sus principales actores en un capitulo poco estudiado, las relaciones internacionales de la prensa, la relevancia de este estudio radica en el hecho de abrirse a los debates y la reflexión actuales ayudando a comprender los fracasos y realizaciones de la contemporaneidad.

Palabras clave: Historia de la Prensa, Historia cultural, Periodismo, Periodistas, Asociaciones de Prensa, Conferencias Internacionales de Prensa, Democracia, Siglo XX

\section{Introduction}

This study on cultural history intends to demonstrate the importance of the 1898 International Congress of the Press as a relevant event for its time and as a part of the history of the press and journalism, mainly because of the themes and debates that were promoted by its participants. As the Congress took place at the turn of the twentieth century, a period of transition, it portrayed the integration between the evolution of the democratic society and the changing identity of journalism, now seen as an independent and specialized profession. When combined with a specific writing style, the profession assumed, at that time, the accuracy and the objective view of reality as journalistic truth. Moreover, the twentieth century brought with not only the dawn of the press as a mega-industry and the establishment of the position of a journalist as an employee in a global cultural and political context, but it also favored the emergence of class Associations, social alliances and cleavages.

These were the main themes that resulted in theories discussed in the event and that turned it into a milestone for the future journalists. Firstly, we analyze the context in which the Congress takes place, that is, the process of internationalization of issues that concerned the men of the press and entailed a reflection on the role of the press and its agents. Secondly, we deal with the main issues that were debated in the Congress and that, as we will see, would continue to be debated even after the Congress happens. These topics will be, therefore, updated throughout this study and seen from different angles and points of view. All the concepts and ideas will be approached in a historical connection rather than philosophically, since we mean to relate ideas and facts dynamically.

Despite having people coming from different countries and geographical areas, the exhibition of ideas that took place during the Lisbon Congress demonstrates that the clashes in the debates happened due to the position each individual occupied in the journalistic industry, showing that social class and profession were more relevant within democratic societies than the places where participants came from.

When referring to the Lisbon congress, we will use as our main support the official rapport of the International Union of the Press Associations, because it corresponds with and confirms the Compte rendu des travaux du 5éme Congrès International de la Presse from 1899 when compared with other sources, such as the main newspapers published in Portugal which followed the event for at least a month, and all the communications made at the congress and published separately.

During the last decade of the 19th century and at least until the First World War, international press conferences were of vital importance to the advancement of journalism and the journalistic profession (FEYEL, 1995; MIRANDA, 2005: BJORK, 2005). This sort of gilded age of the world press that presented itself as universal press, which 
meant that its agents were fully aware of its meta cultural and meta political attributes, as well as the weight it bore, as a legitimate moral representative of the people, in a broader sense ${ }^{2}$, provided the support for these annual meetings and socializations and for the discovery and enhancement of a greater professional identity monitoring and contributing to the evolution of the democratic society. ${ }^{3}$

This identity in formation, framed by an international association and the international congresses, motivated the growth of professional associations in each participating country, and the consequent need of a code of conduct ${ }^{4}$, which opened the way for a peaceful conquest of professional independence from the political and literary classes. Even though the journalist becomes more and more a wage earner, as we will perceive from the debates of Lisbon Congress, the idea of moral mission was always an essential part of the definition of the role of the press as a profession.

The importance of international associations of press was also in connection with the characteristics of the profession. The newspapers were the windows for the news of the world; the journalists needed to have a wide cultural and political knowledge as well as the access to the information of the main international events. This share of interests and the beginning of professional careers took the national associations to the next level of organization.

In 1893 in Chicago, coinciding with an international exposition, the first international congress of the press happened. No conclusions were taken or lines to follow, but many recurrent topics came to discussion, namely the role of the press on daily bases, the freedom of the press, and the moral mission to help to avoid misunderstandings between nations and contribute to world peace and progress (KUBKA \& NORDENTHENG, 1986, pp.41-50; HAMELINK, 2001, pp.21-27).

In 1894, at the first international congress of the journalists' associations in Belgium, it was decided to create an International Union of the Press Associations ${ }^{5}$, organization that could defend and represent the interests of the press and journalists all over the world. A committee elected at Anvers discussed the statutes (SINDICATO; FEDERAZIONE, 1897, pp.500-505) and all their deontological import, this discussion continued at the following conferences, in 1895 in Bordeaux and in 1896 in Budapest, where they were finally approved ${ }^{6}$. Intended to be a law and code of conduct for press members, the first

\footnotetext{
"At the side of the diplomats credited as Governments plenipotentiaries, I greet the Press delegates as ambassadors of the people." This is our translation from?: «À côté des diplomates accrédité comme les plénipotentiaires des Gouvernements, je salue les délégués de la Presse comme les ambassadeurs des peuples». (CONGRĖS, 1889, p. 38).

3 "Our great solicitude for the solidarity of the professional and moral interests of the day by day historians - as they called us with irony - cannot be stopped anymore [...] No dear sirs, another time other custom. As with any other political or social question, the situation of the press will knock at the door of the next century. The joke that consists of saying that the journalists are people, who in general failed their vocation, has had its time. No, we never failed a thing. We always worked by sacrificing ourselves, our health, and the happiness of our family, for the public interest." This is our translation from «Notre grande sollicitude pour la solidarite des interêts professionnels et moraux des historiens du jour le jour - comme on nous appelle avec une pointe d'ironie - ne pourra plus être enrayée [...] Non, Messieurs, autre temps, autres mœurs. Comme toutes autres questions politiques et sociales, la question de la situation de la Presse frappera fortement à la porte du prochain siècle. La plaisanterie qui consiste à dire que les journalistes sont gens que généralement ont manqué leur vocation, a fait son temps. Non, nous n'avons jamais rien manqué. Nous avons toujours travaillé en sacrifiant notre personne, notre santé, le bonheur de notre famille pour l'intérêt public». (CONGRĖS, 1889, p. 16-17).

4 "As soon as the International Association was founded, our first care was to work to give to the Press a code and a law." Tihis is our translation from: «Lorsque l'Association international a été fondée, notre premier soin a été de travailler à constituer à la Presse, un code et un droit». (CONGRĖS, 1889, p. 47).

5 "The first International Congress of the Associations of the Press, in Anvers in July 1894, decided in principle on the creation of a federation of Press Associations from different countries, and nominated a Commission to prepare the Statutes." This is our translation from « Le premier Congrès international des Associations de Presse, tenu à Anvers au mois de juillet 1894, décida en principe la création d'une fédération entre les Associations de Presse des différents pays, et nomma une Commission pour en préparer les Statuts» (CONGRĖS, 1889, p.3).

6 "The second Congress decided that the voted Status would be distributed to Press Associations of the entire world, that the Associations would be invited to state their adhesion within six months and to send their delegates to the Budapest Congress to ratify the so called Statutes and to constitute the Management Committee of the Central Bureau. The Commission faithfully executed the decisions of the Bordeaux Congress, and the Congress of Budapest, in a memorable session on the $6^{\text {th }}$ June 1896, pronounced with acclamation the ratification of the Statues, in this way giving the final consecration to the Press Union." This is our translation from «Le second Congrès décida que les Statuts votés seraient distribués aux Associations de Presse du monde entier, que ces Associations seraient invitées à exprimer leur adhésion dans le délai de six mois et à envoyer leurs délégués au Congrès de Budapest pour ratifier les dits Statuts et constituer le Comité de Direction du Bureau Central. La Commission exécuta fidèlement les décisions du Congrès de Bordeaux, et le Congrès de Budapest, en une séance mémorable, le 16 Juin 1896, prononça d'acclamation la ratification des Statuts, donnant ainsi à la grande œuvre de l'Union internationale de la Presse la consécration définitive» (CONGRĖS, 1889, p. 3-4).
} 
articles clearly state a few principles of inclusion, declaring not to refuse anyone for his political believes, race, religion or nationality, and affirmed the disposition to contribute to the intellectual and material improvement of every colleague in order that trough this achievements be provided a quality service to the people and nations, and at the same time, to be able to promote harmony between governments.

Lisbon shared the same concerns when the 1898 International Congress received the journalists and press members from all over the world, once Portuguese journalists were participants in the International Union from its beginning.

The event shows us three important points that we would like to highlight. Firstly, that the objectives and problems to resolve were common to every participant country and discussed with equity, by excluding differences of ranking or wealth. The fact that they consider themselves intellectuals and man of letters with a moral mission contributed to give a democratic example of the Union's actions and internal organization.

Secondly, the fact of being an event quite open to all members of the press with equal representation, allow us to once more connect the event not only to the history of the press but also to the evolution and growth of democratic societies and the social consequences that put the majority of journalists in the situation of employees depending on a salary to live. In this sense the diversity of national associations represented, some mixed, meaning, composed for all members of the press including owners, editors and journalists; and others functioning as syndicates defending journalists interests; though had contributed positively for the debate and managed consensus, demonstrated us that the turn of the 19 century and the beginning of the 20 was a period that the social cleavages were still encompassed on the faith in the progressive well-faire of mankind.

Thirdly, some of the results of the 1898 Congress worth mentioning, as the approval of press credentials and the consequent creation of a list and a support network for correspondents; or the unanimous vote for the Central Bureau of the Press Union to became an International Court of Arbitration for the Press for ethical and deontological matters as provided in the statutes; and last but not least, the report made by a North American and a French, this debate and final approval as a directive to all national associations to implement a college degree of journalism in each country, based in a program that combined theoretical classes with practical internships in newspapers.

The option of contextualizing the featured event and the state of the art of the press, the journalism and the journalists' conditions, through as many points of view and angles of analysis as possible, helped to understand the object and legitimacy of this study.

\section{The Lisbon Congress in Context}

The event promoted by the International Press organization was the result of national efforts to structure a coherent response to the specific transnational features of journalism and the profession of journalist.

Also, without wanting to reverse the social order,
we ask for our place under the sun, not a tolera-
ted place, but a well-defined one. In this sense,
we brought together all the Press Societies
of the world wishing to join a well-cemented
alliance, and we have formed a body, based on
common interests, which claims its affirmation
and its definitive establishment in this enterprise?

It is interesting to follow the process of trying to combine, in a democratic way, the national component with the international one, establishing a co-federation and at the same time respecting wills through constant consultation, and by the defense of equity in representation and management.

It should also be added that given the importance of the power and prestige of the press at the time, this whole confederative system was meant to function in an exemplary political way for civil society in the countries involved.

\footnotetext{
7 «Aussi, sans vouloir renverser l'ordre social, nous demandons notre place au soleil, non pas une place tolérée, mais une place bien marquée, bien définie. Dans ce but, nous avons réuni en une alliance bien cimentée et inébranlable toutes les Sociétés de Presse du monde qui y voulait adhérer, et nous avons formé un corps, basé sur les intérêts communs, qui réclament leur affirmation et leur établissement définitif dans cette entreprise» (CONGRĖS, 1889, p. 17).
} 
From all the forces of journalism, spread out around the world, we tried to form a literary army whose members are immediately recognized for their personal dignity, for their patriotism, for the probity of their sights and for their honesty in the exercise of their functions. This is, so to speak, the soul of our body. It is the internationalization of their firm will, unshakeable in doing good and, one day, becoming one of the most important factors for the definitive establishment of peace and harmony among nations. ${ }^{8}$

The managing board of the Central Bureau of the press corresponded to the number of associations of the various country members, and established representation proportional to the number of associations and registered journalists in each country. In addition to the accession of most European countries, in the 4 th Congress in Stockholm, the Danish and the American Associations were also accepted. Thomas J. Keenan's Press Club of Pittsburgh would become the greatest distributer of the International Union of the Press Associations in the United States?. In 1898 this led to the participation of the Press clubs of Boston and New York in the Lisbon Congress and Keenan's election for the managing board of the Central Bureau. Memberships of associations for the Lisbon Congress occurred from Argentina ${ }^{10}$, Finland and England along with the names of those elected to the board of the Bureau which emphasized the increasing prestige of the International Union of the Press Associations: "The more the Press shows it is united, the more it appears conscientious of its lofty mission and the more it will be able to obtain just privileges. This is one of the most important results of the Congresses."11 The fact that only through national associations could someone belong or be elected to the Bureau, actively participate in the annual meetings ${ }^{12}$, and from there enjoy, as a member of the professional class, the measures adopted, would lead to an effort to promote the national organizations of press professionals in most countries ${ }^{13}$.

As a consequence and as long as the statutes were accepted and respected, each country could be represented by several press associations, and in this context there was a wide range of members accepted to the international congresses, from the press clubs to union-based associations and also those more intellectual or specialized, not forgetting those still encompassing journalists and writers (FRÖLICH \& HOLTTZ BACHA, 2003, pp.93135: MIRANDA, 2014), or those with a more political or religious agenda, all within a democratic point of view and without external or governmental pressures. The first graphic below exemplifies the diversity of kinds of press associations present in Lisbon Congress, and the second one shows their distribution for countries ${ }^{14}$

\footnotetext{
8 «De toutes les forces du journalisme, éparse dans le monde entier, nous tâchons de former une armée littéraire dont les membres soient immédiatement reconnaissables par leur dignité personnelle, par leur amour de la Patrie, par la probité de leurs vues et par leur honnêteté dans l'exercice de leurs fonctions. Voilà pour ainsi l'âme de notre corps. C'est l'internationalisation de la volonté ferme, inébranlable de faire le bien et de devenir un jour les facteurs les plus résolus de l'établissement définitif de la paix et de la concorde entre les nations» (CONGRĖS, 1889, pp. 28-29).

9 "Soon, we hope, by enrolling in great number the United States Associations this will take the American delegation to the level of importance it should have." This is our translation from «Bientôt, nous l'espérons, Les Associations des Etats-Unis se faisant inscrire en grand nombre, amèneront la délégation américaine à l'importance qu'elle doit attendre» (CONGRĖS, 1889, p.36).

${ }_{10}$ In Latin America the Associations from Mexico and Chile are also mentioned as members of the International Union of the Press (CONGRĖS, 1889, p.75)

11 «Plus la Presse se montrera unie, plus elle apparaitra consciencieuse de sa haute mission et plus elle pourra conquérir de justes privilèges. C'est là un des grands résultats de nos Congrès» (CONGRĖS, 1889, p.34).

12 This restriction was not completely rigid. In the first congress in 1894, and thinking about Brazil the Portuguese Sebastião de MagaLhães Lima and the Spanish Alonzo Beraza both members of the Central Bureau, recalling the Argentine and other Latin American countries, defended and managed to approve the fact that those countries which had no press associations could send properly authorized representatives. The idea was to continue to encourage the professional societies, but some exceptions had been made to extend the influence of the international organization as much as possible.

13 In Portugal, for instance, the first Press Association appeared in 1880 with an Association for journalists and writers, but closer to the Lisbon Congress two more were created in 1896 and 1897. The Lisbon Association of Journalist, and the Portuguese Press Association. The latter established itself in a more comprehensive way as a defender of all press workers and above all in support of the freedom and the professional independence of journalists, closer to the function of a Trade Union.

14 All the graphs are calculated from the list of names of the journalists present in the Lisbon Congress and their respective country. association and situation in the congress (CONGRĖS, 1889, p.137-146).
} 


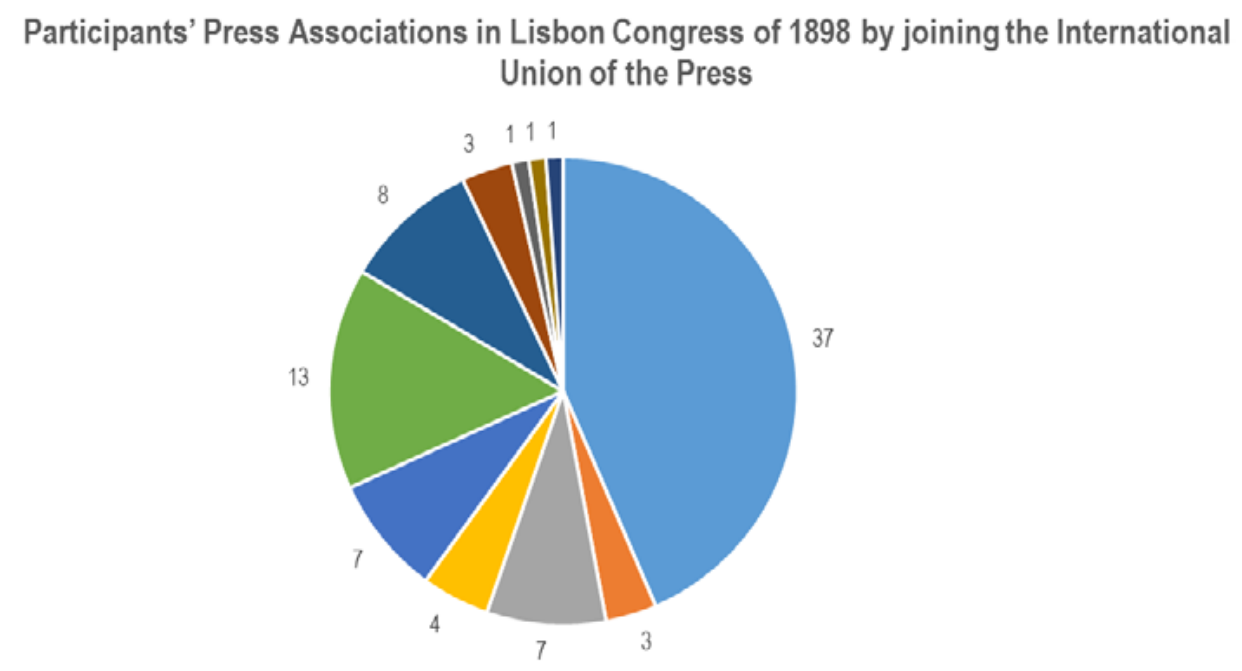

- Press Associations
- Syndicate Press Associations

- Cultural Press Associations
- Press International Associations

- Journalists Associations

- Judicial International Association
- Writers and Journalists Associations $=$ Foreign Press Associations

- Political Press Associations

- Colonial Press Associations

- Christian Press Associations
Countries and Press Associations participants in the Lisbon Congress of 1898

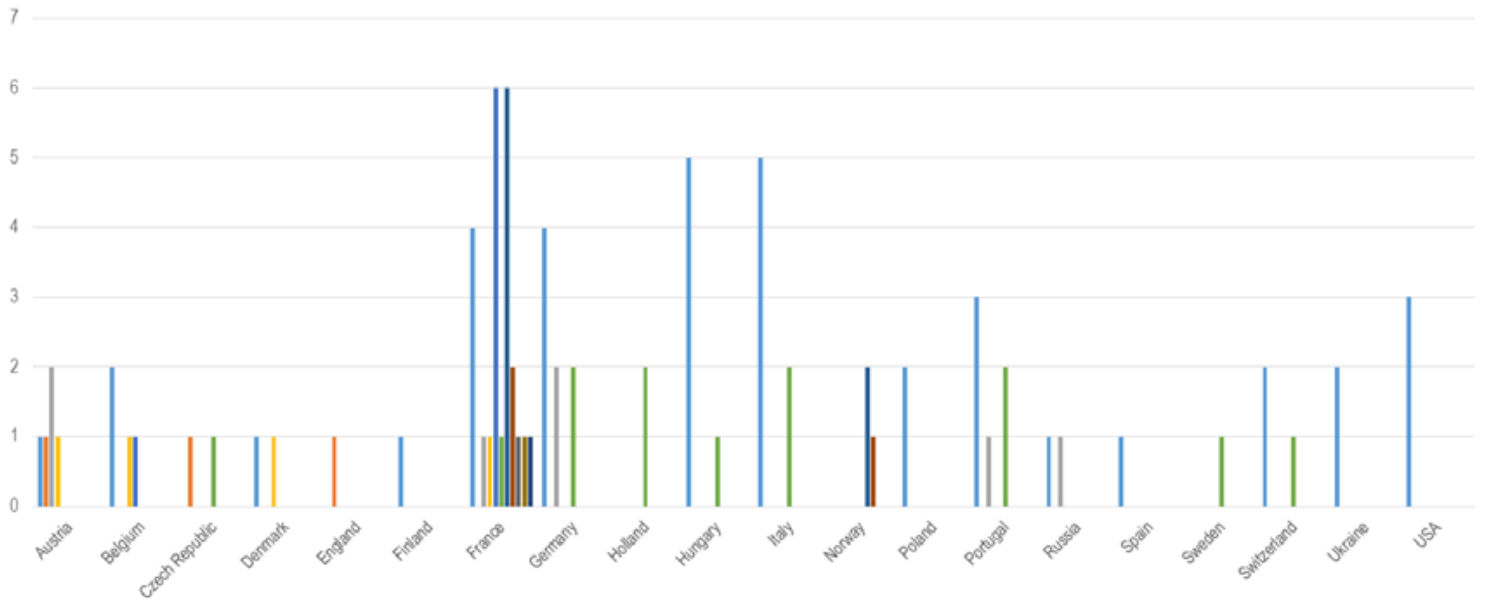

In addition, the statute reflected a liberaldemocratic society, where respect for freedom of the press was politically assumed ${ }^{15}$. In fact, the Bureau rejected some associations because their situation did not correspond to statutory requirements for the definition of a well-framed professional profile, or the lack of a political regime which made the existence of a free and independent press possible. This meant that the independence of the associations from governments had to be assured and that their main objective would be clearly defined as being the improvement of the press and journalists. "Over the course of our deliberations [the Central Bureaul, we have either accepted the admission of Associations whose program was not sufficiently defined, or rejected the demands for the acceptance of Societies whose situation did not meet all the statutory prescriptions, given both their political or professional profile."16

15 "The Press's president, M. Singer, defined, in convincing words, its generous mandate and how it clearly showed the advantages of a union that might embrace the times and the people under the primate of liberty. Always grateful, the Press thanks the nations that acclaim it, the great ones who understand it, and the sovereigns who welcome it." This is our translation of : «Par la bouche de son président, $M$. Singer, la Presse a défini en termes convaincants son généreux mandat, et elle a fait clairement ressortir les avantages d'une union qui peut embrasser les temps et les peuples sous l'égide de la liberté. Reconnaissante toujours, elle a remercié, enfin avec âme, les nations qui l'acclament, les grands qui la comprennent, les souverains qui l'accueillent» (CONGRĖS, 1889, p.39).

16 Victor Taunay states : «Au cours de nos délibérations [du Bureau Central], nous avons, par contre, ou différé l'admission d'Associations dont le programme n'était point suffisamment défini, ou rejeté les demandes d'acceptation de Sociétés dont la situation ne répondait point aux prescriptions des Statuts, au double point de vue de la politique ou de la caractérisation professionnelle « (CONGRĖS, 1889, p. 36). 
The requirements for a favorable policy for the development and independence of the Press, as the disseminator of ideas and civilization by excellence and journalism as a profession, were bound up with the requirement for an apolitical posture, that is, not a denial of politics but overcoming it through means of the principle of moral and professional ethics. To the objectivity and honesty of the journalist and journalism should match spaces well delimited, corresponding to each an appropriate section within the newspaper for reports, commentaries, opinions and news.

At the time of the Lisbon Congress a few restrictive press laws were in force in Portugal and for political reasons some journalists were persecuted, and newspapers were closed. Censorship had not been implemented, but a few laws against anarchist bomb attacks, served as an excuse to those actions against government press opposition. The Portuguese Press Association prepared a motion to present on the 26 September, the first day of congress, to protest those persecutions. A few Italian delegates joined the motion to extend the protest and to support the Italian journalists arrested in the riots in Milan. The Central Bureau and the presidency of the Congress refused to accept the motion because they did not want to harass the host country's government. Several radical Portuguese newspapers, A Marselhesa (1896-1898), A Lanterna (1898-1899), A Vanguarda (1891-1911), displayed their discontent on their first pages on $27^{\text {th }}$ September 1898. To them the position of the Bureau of the press was as inconceivable as was such an event organized for the press taking place in a country where the government welcomed foreign journalists, while at the same time harassing, those Portuguese journalists who political opposed him.

Nevertheless, the speech of the President of the International Union of the Press Association, the Austrian W. Singer, at the opening of Congress in Lisbon, summarized the ethical principles embodied in the statutes of the organization. This reflected not only compliance with democratic ethics but, above all, a tendency to have democratic societies as members and achieving social status through commitment and success at a professional level.

When we started our solidarity work, many doubts arose about the viability of our enterprise. In fact, the task was not easy. All the devotion, all the wise efforts, all the patience, doubled with an untiring optimism was needed to form an organization so extensive and to make such an inevitably complicated mechanism function. But we are happily placed - I believe - on excellent grounds. Above all, we have taken away the possibility of division i.e. the political, the national and religious questions, and we have put forward, however, the moral and professional questions that have given our Society the wanted and visible imprint of honor and dignity. ${ }^{17}$

The feeling of the internationalization of these principles and aspirations, the sharing of wills in search of a better world, showed the spirit of optimism with which the century ended ${ }^{18}$, and also the unshakable belief in the positive role that the press was called upon to fulfill on behalf of that task. ${ }^{19}$

It was, therefore, within this good spirit that the Lisbon Congress began in September of 1898:

17 «Lorsque nous avons commencé notre œuvre de solidarité, de graves doutes se sont élevés sur la viabilité de notre entreprise. En effet, la tâche n'était pas facile. Il fallait tous les dévouements, tous les efforts sages, toute la patience, doublée d'un optimisme infatigable, pour former une organisation si étendue et pour faire fonctionner un mécanisme nécessairement compliqué. Mais fort heureusement nous sommes placés - je le crois - sur un excellent terrain. Nous avons écarté, avant tout, les ferment de division, c'est-à-dire les questions politiques, les questions de nationalité et de religion, et nous avons mis, cependant, en avant les questions professionnelles et les questions morales, qui donnent à notre Société l'empreinte voulue et visible de l'honneur et de la dignité» (CONGRĖS, 1889, p.28) 18 "At present, we feel life running through our veins. Strength comes to us, our organization creates roots and it is well implanted in this friendly country, Portugal." This is our translation from «A présent, nous sentons courir la vie dans nos veines. La force nous vient, notre organisation prend racine et elle est bien implantée maintenant dans ce pays ami, le Portugal» (CONGRĖS, 1889, p.28).

${ }_{19}$ "Yes, we form a plot, but in Lamartine's [Alphonse Lamartine, French writer and politician (1790-1869)] words, we form a plot of hearts. and we have infallible procedures that propel us straight to success that are the friendship, the clear discernment of our permanent interests and our frank and loyal confraternity. We have as much as possible, made the personal issues, the misunderstandings born from ignorance, the harmful preconceptions, disappear and we have approached each other with the good will of each other's appreciation to remind us all, that in the measure of our talent and situation, we are destined to work together with the same means for civilization, progress and justice." This is our translation from : «Oui, nous formons une conjuration, mais, pour employer le mot de Lamartine, nous formons une conjuration des cœurs, et nous avons un procédé infaillible qui mène droit à la réussite, c'est l'amitié, le discernement clair de nos intérêts permanents et la confraternité franche et loyale. Nous faisons disparaître, autant que possible, les polémiques personnelles, les malentendus nés de l'inconnu, de préjugés nuisibles, et nous nous rapprochons les uns des autres avec la bonne intention de nous apprécier justement et de nous rappeler que nous tous, dans la mesure de notre talent et de notre situation, nous sommes destinés à travailler avec les mêmes moyens pour la civilisation, le progrès et la justice» (CONGRĖS, 1889, p.28). 
"We came to Portugal to deal with professional questions which matter to the entire world, because today the supreme power, the voice of opinion, is the Press [...] The Press is the express train of human thought."20

During the month of September till the middle of October 1898, the main Portuguese daily newspapers, o Diário de Notícias (1865- ), o Século (1881-1983), O Correio Nacional (1893-1900) and a Batalha (1896-1900), almost every day announced the preparations for the congress, the drawing up of the programs of work and leisure, and counted 250 delegates and 376 persons in all, including guests and family.

Looking back and seeing, year after year, the number of periodicals growing, their actions expanding, and their field of exploration win- ning over the world. How many did we enroll in the Associations of the Central Bureau? Twelve thousand, perhaps fifteen thousand, tomorrow twenty thousand [...] and who knows in ten years. We are an army which organizes itself for the greater good of civilization and progress of mankind. ${ }^{21}$

Most of the journalists present in Lisbon came from Holland, on account of the invitation that the International Union had received to organize the presence of the Press in attending and disclosing the investiture of Queen Wilhelmina (1898 to 1948). Boats went to America and trains all over Europe to bring the journalists to Holland and from there to the Congress in Portugal for free, all this logistics' organization implied a large official and unofficial supports. See the graphic bellow that shows the number of participants and adherents by country.

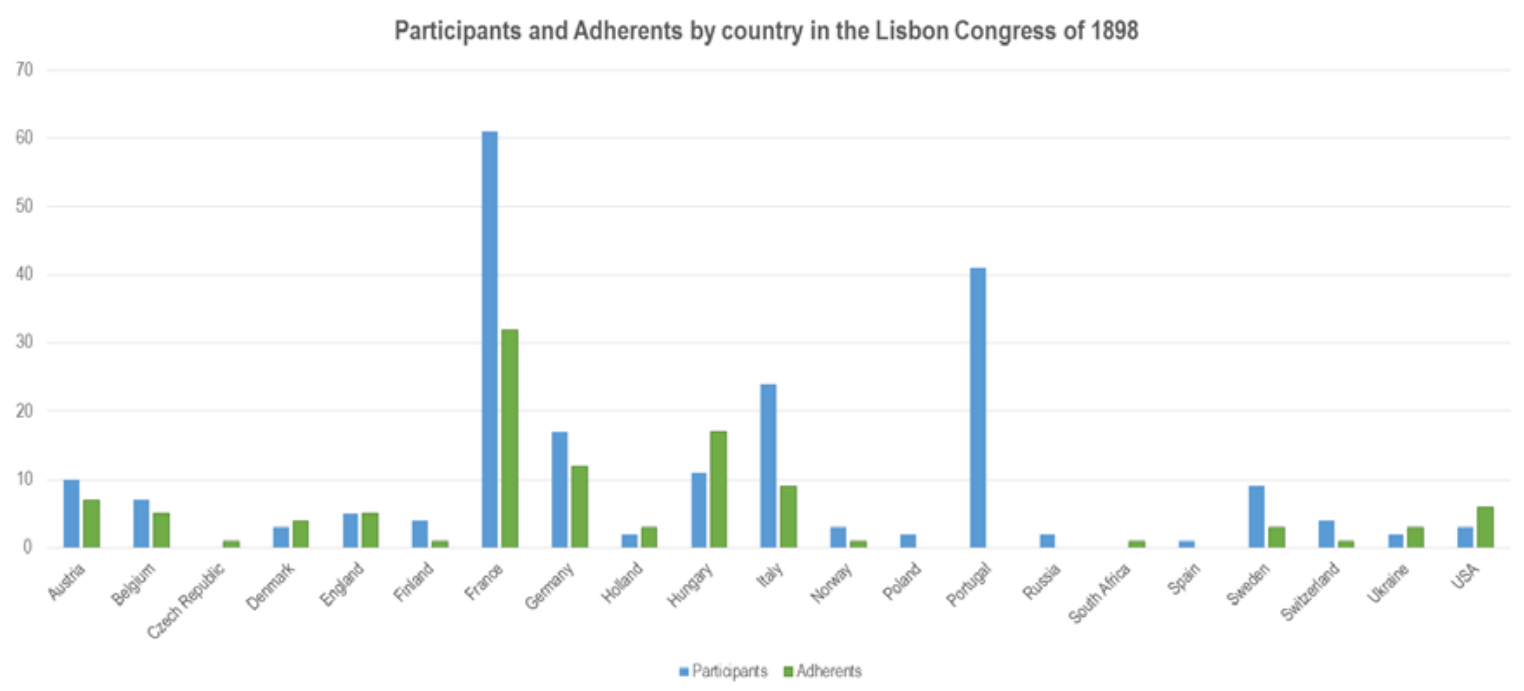

Hosting such an event as an active member of the Bureau gave the host country and all those involved certain publicity advantages. The Portuguese periodicals mentioned some of these examples: free transportation by boat or train from country to country for all congressmen; welcoming banquets and tours organized and hosted by the local authorities of each town and village they visited; furthermore, the recognition of the importance of the event was often reflected in the presence of governments and sovereigns. So, before the Lisbon Congress ended, the congresses for the following years until 1903 had already been planned (Italy, France, Switzerland, Austria and Germany).

The subjects to be discussed by the delegates of the press associations were mostly themes resulting from previous conferences, some of which were resolved and finally approved in Portugal. Others, despite progress, were held over to future meetings.

20 Jules Claretie states: « Nous venions en Portugal pour traiter des traiter des questions professionnelles qui intéressent le monde entier, parce qu'aujourd'hui le pouvoir suprême, la voix de l'opinion, c'est la Presse [...] La Presse est le train express de la pensée humaine!»» (CONGRĖS, 1889, p.107).

${ }_{21}$ Paul Oeker and Albert Bataille state: «Jetez un coup d'œil en arrière et voyez, d'année en année, le nombre des journaux grandir, leur action s'étendre, leur champ d'exploration gagner jusqu'au bout du monde. Combien sommes-nous dans les associations inscrites au Bureau Central ? Douze mille, quinze mille peut-être, demain vingt mille... et qui saurait dire le chiffre dans dix ans. Nous sommes une armée qui s'organise pour le grand bien de la civilisation et du progrès de l'humanité» (CONGRĖS, 1889, p.127). 
The special price negotiated with the various governments for telegraph use by the press saw some improvements, and the representatives of Spain and France were charged with passing information to all countries regarding the agreements reached, which were quite advantageous for newspapers and journalists ${ }^{22}$.

The report on the comparative study of press legislation in the several countries, for example. was also held over to the next congress. For those seeking more favorable legislative conformity regarding the development of the press, this was important and a great deal of information had already been obtained which required processing in the appropriate manner, and the journalists in charge of this study were awaiting even more information, particularly from Latin America ${ }^{23}$, to complete the final report which was therefore held over to the next year in Rome.

Another matter of great importance being discussed was the issue of correspondents ${ }^{24}$. It had become necessary to streamline the relationship of journalists with newspapers anywhere in the world, that is, it was necessary to establish a Bureau to defend press professionals internationally, as newspaper correspondents or as freelancers, in order to privilege certain events of global importance. The drawing up of correspondent lists and their distribution to newspaper managements was a work in progress in 1898, with the resulting advantages acquired for hundreds of journalists by then. ${ }^{25}$

Creating an identity card for press members was another important decision taken by the Congress, using the prestige obtained by the International Union of the Press, and secondly providing another advantage by being linked to national associations since both were needed to take responsibility for the accreditation of each media professional.

The International Union of the Press Associations was gaining prestige and credibility, so when it was proposed that the Central Bureau became an International Court of Arbitration for the Press, the Congress unanimously approved this. ${ }^{26}$

\section{The Lisbon Congress: Main Issues and Debates}

Underpinning the history of the press in connection with processes of adaptation and growth of democratic culture societies within the framework of this new reality, several transversal and global cleavages occurred on both sides of the Atlantic within the so-called occidental political geography. In all the themes and debates presented throughout the Lisbon Congress, these cleavages either implicitly or explicitly emerged: between large and small newspapers; the local or regional press and the national press; journalists and newspaper editors; newspaper editors and owners; journalists and the barons of industry: "For the moment, we have not yet assured the material interests of journalism, and the first matter to which we have a solution lthe price drop in telegraph rates] provided greater satisfaction to newspapers than to journalists. It's true that the advantages achieved for the newspapers, lead to undeniable advantages for its employees."27

These first international meetings, Lisbon included, though they showed an admirable effort of consensus and managed to join several kinds of national associations, as seen, the natural contradictions brought for industrial growth and democratic massification disrupt during the Lisbon debates referring, in consequence, to the professional structuring of journalism and to what it meant to be a member of the press, and the resulting credibility in a desired free and democratic society: "The Steering Committee will be in charge of making an inquiry, as complete as possible, into the social, moral and material conditions of journalists

\footnotetext{
CONGRĖS, 1889, p. 43-44

CONGRĖS, 1889, p. 74-75

CONGRĖS, 1889, p. 35- 45

BUREAU, 1898

CONGRES, 1889, p. 85-88
}

Alonso Beraza « Pour le moment, nous n'avons pas encore assuré les intérêts matériels du journalisme, et la première question sur laquelle nous avons obtenu une solution [la baisse des prix dans les tarifs télégraphiques] satisfait plutôt les journaux que les journalistes. Il est vrai que des avantages accordés aux journaux découlent des avantages indéniables pour les collaborateurs" (Ibidem, p. 78). 
in the various countries, especially concerning the reciprocal rights and duties of editors and employees, the way of hiring, payment, etc."28

The Spanish congress attendee, Alonzo Beraza, when referring to the price drop in the telegraph rates which had been achieved in some countries and its on-going discussion in other countries, and to the creation of a Bureau of Correspondents, demonstrated how these achievements greatly facilitated communications and globalized information ${ }^{29}$, by sending journalists, or especially, through credited correspondents. Therefore, he clearly stated the problem regarding to the structural operation of the newspapers that, in most of cases, were already at the level of any profitable company.

"In the words of our colleague, the public need to know that journalism is a career like any other, as ungrateful as any other, but also as honorable. My friends think that there are two ways of making it as honorable as possible: moral and material improvements. What we can do right now is to improve journalism. This concerns both the Congress and the Central Bureau."30

The problem was how to deal with journalism, both as a career and a way of living subject to hierarchical pressure, and as a cultural and political mission with a moral duty. Given the impossibility of ignoring these facts, the solution found for the problem was to present it as two faces of the same coin.

This issue revealed problems directly connected to the development of the newspaper industry, adaptation to the principle of democracy and to the correspondent equity and formal equality of the agents, as a goal of the representative system: "The journalists needed to become more independent; it was also important for them to no longer be employees of the newspaper's editor and become collaborators both from the material and moral point of view." 31

The problem of copyrighting newspaper articles on political or social themes was another issue resolved in Lisbon ${ }^{32}$. The protection of authorial rights for articles involving literary or artistic reproduction was assured by international conventions such as the 1896 Berne convention and was ratified by the 4th International Congress of the Press of Stockholm in $1897^{33}$. However, the authorial rights of political or socio-economic interest articles did not obtain the necessary consensus and for that reason it was put up for discussion in Lisbon.

In fact, during the discussion, it was noted that there are two different ways of looking at journalism: On the one hand, by taking the international arena into account, or, on the other hand, by analyzing each country separately. Not being completely antagonistic, these even had the intransigent defense of the journalistic class in common, but also had different views regarding freedom of reprinting, which showed conceptual divergences. If, as some argued, sculptors, painters or authors of any literary work were protected from plagiarism and unfair competition, journalists should also be. Since

\footnotetext{
28 Thomas Steinhertz : «Que le Comité de Direction soit chargé de faire procéder à une enquête aussi complète que possible sur la situation sociale, morale et matérielle des journalistes des différent pays, notamment en ce qui concerne les droits et les devoirs réciproques des directeurs et des collaborateurs, le mode d'engagement, les paiements, etc.» (Compte rendu..., p. 74).

29 "It often happens, even that the richest and better organized newspapers, find themselves incapable, in certain circumstances, of satisfying the legitimate curiosity of the public. It is only by chance that newspapers are sometimes informed of important events produced in distant locations, and with difficult access, where there are no correspondents, and where it is not possible to send an editor in a timely manner. A catastrophe, a crime, the death of an eminent character, a revolutionary movement, or another important political or simply sensational event, can unexpectedly happen from one moment to another in places from where is not possible to have information except in a slow and difficult manner." This is our translation from « Il arrive souvent, même aux journaux les plus riches et les mieux organisés, de se trouver incapables dans certaines circonstances de satisfaire la légitime curiosité du publique. Ce n'est que par hasard que les journaux sont informés parfois d'évènements importants qui se produisent dans des localités éloignées, peu connues, de difficile accès, ou ils manquent de correspondants, et où il ne leur est pas possible d'envoyer un rédacteur en temps opportun. Une grande catastrophe, un crime, la mort d'un personnage éminent, un mouvement révolutionnaire, ou tout autre événement politique important ou simplement sensationnel, peuvent se produire d'un moment à l'autre, d'une façon inattendue, en des localités d'où il n'est possible d'avoir des renseignements qu'avec lenteur et difficulté» (CONGRĖS, 1889, p.116).

30 Jean Bernard : «Il faut, suivant l'expression de notre confrère, que le public sache que le journalisme est une carrière comme une autre, aussi ingrate, mais aussi honorable. Mes amis pensent que, pour la rendre aussi honorable que possible, il y a deux moyens : l'épuration morale et l'amélioration matérielle [...] Ce qu'ont peu faire dès à présent, c'est améliorer le journalisme. Cela regarde le Congrès et son Bureau Central» (Ibidem, p. 78).

31 "Il faudrait rendre les journalistes plus indépendants, il faudrait qu'ils ne fussent plus les employés du directeur du journal, mais des collaborateurs au double point de vue matériel et moral» (Ibidem, p. 79).

32 Compte rendu..., p. 120-125

33 Ibidem, p. 47- 48 and p. 121-122
} 
intangible property was as sacred as material property. Some congressmen went further in this regard and argued that, in addition to authorization for use, a payment should also be made.

In contrast, several congressmen defined journalism as the noble mission of propagating ideas, and so preventing this free dissemination went against all the principles and traditions of journalism. Nevertheless, a consensus was possible because the former did not want to stifle discussion, commentary, or the advertising of ideas and the latter also condemned the unfair competition of certain newspapers which existed by plundering articles. In the final version, with the general agreement of the congress, it was thus decided to safeguard free reproduction as long as newspapers cited authorship, and the reproduction of articles, was forbidden when the author so decided (CONGRĖS, 1889, p.69)34.

In this debate on author's rights in political opinion articles, several of the issues listed above were discussed. Albert Bataille, a French journalist and member of the Central Bureau, was prominent in arguing in favor of some prohibitions against the abuse of those who lived from plundering newspaper articles which was damaging to journalists and journalism. Within the same framework, other related issues were raised.

A Portuguese congress attendee, António Alves Correia, for example, who favored total freedom to reproduce political texts provided these were properly referenced, raised a new problem or cleavage to which the Congress could not provide a complete answer, by differentiating the freedom of the journalist from the freedom of the newspaper's owner: "I want the free reproduction of my writings, and if we enable this to be forbidden, the owner of the newspaper where I write can put this prohibition into force even if I don't agree with it. The owner will refuse whatever the editor would desire" lour translation] 35 (CONGRĖS, 1889, p.68).

However, both newspaper owners and journalists agreed on two aspects. Firstly, they agreed to defend the small newspapers by authorizing the reproduction of political articles provided these were well referenced and identified, otherwise, as the English representatives demonstrated with the full agreement of the Lisbon Congress, this would mean their termination as well as the regional newspapers. Secondly, it was acknowledged that there was a need to prevent anonymous societies of shareholders from acquiring and editing newspapers if the latter did not have an actual editorial office and were living off the looting of others, with great harm to readers and press professionals: "This procedure isn't only contrary to loyalty, and doesn't only constitute a rude act, but it also results in great harm to the Press, because many of us, in this way, are deprived of a way to make a living; while if there was a legal brake, the numerous shareholder companies who saved on editorial costs, couldn't do this anymore."36

The press had transformed itself into a profitable business with all the consequences arising from this. When carrying out a balanced review of the coming into existence of the international organization press, the President Jules Claretie, following the Universalist tone of the Congress, sought to marry its ethical and moral mission with the living conditions of journalists.

In fact, each one of our steps has shown progress. After five years, one can measure the steps already taken. It was not only through parties that these meetings were held throughout the world: it was through material and moral conquests that will one day ensure that editors will have the material and intellectual conditions they crave for. ${ }^{37}$

\footnotetext{
34 Compte rendu..., p. 69

35 "Je veux la libre reproduction de mes écrits, et si l'on l'admet la faculté de l'interdire, le propriétaire du journal où j'écris viendra mettre cette mention d'interdiction alors même que je ne le voudrais pas. Le propriétaire refusera ce que le rédacteur aurait désiré» (CONGRĖS 1889, p. 68).

36 Albert Bataille states: «Ce procédé n'est pas seulement contraire à la loyauté, il ne constitue pas seulement un acte indélicat, il porte le plus grand préjudice à la Presse, car beaucoup d'entre nous sont ainsi privés du moyen de gagner leur vie; tandis que, s'il y avait un frein légal, les Compagnies d'actionnaires, très nombreuses, qui économisent leurs frais de rédaction, ne pourraient plus le faire» (CONGRĖS, 1889, p.50)

37 «Chacune de nos étapes, en effet, a marqué un progrès. Depuis cinq ans, mesurez les pas qui ont été faits. Ce n'est pas seulement par des fêtes que ces assises ont marquées à travers le monde : c'est par des conquêtes matérielles et morales qu'assureront un jour aux publicistes les conditions d'existence matérielles et intellectuels auxquelles ils peuvent prétendre» (CONGRĖS, 1889, p.50).
} 
However, it was the Swiss congress attendee, Boerlin who touched on the heart of the matter: "Most editors are not independent. They are only employees and not owners of their newspapers. They are constantly one step away from being dismissed."38 During the Lisbon Plenary, it was the Foreign Press Syndicate through the voice of its representative, the Belgian publicist Jean Bernard, who was most forthcoming in equating the problem of independence of the press and members, not so much in relation to political but to economic power.

Even if you take into your own hands the challenge of moralizing journalists, - and you are right in teaching them and in training them - they want lthe journalists from the Foreign Press Syndicatel - I am going to say something huge - us to occupy ourselves with trying to moralize the owners. They want the director to no longer be a vulgar merchant of paper who sells this to their clientele; but to be a true professional journalist, with their careers; and they do not want to see any more coal merchants, just because they are millionaires, becoming newspaper owners. ${ }^{39}$

As verified, if some viewed journalism as a profession with the mission to train and inform, others understood that prestige and power were increasingly connected to the information industry, thus, also connected to the management and ownership of periodical publications with expanding dissemination, corresponding to social recognition and effective power. According to Beraza, not accepting this fact was like not accepting the reality of democratic society.

I don't see how the Congress, or the Committee could prevent a coal merchant from founding a newspaper, getting editors and paying them.
I don't see any practical or material means of opposing to this. I am the co-owner of the biggest newspaper in Madrid [O Liberal], with a circulation of 100, 000 newspapers. I am vice-President of the management committee director and I have been a journalist for 30 years; so I have some experience in this profession. Despite of this, I repeat, I don't see any possible weapon against the invasion of coal merchants concerning newspapers. There is nothing here originating from the legal and common law rules of each country. ${ }^{40}$

Calling upon the previous and subsequent interventions, together with the responses he obtained, the Belgian journalist assumed he belonged to an elite which had the duty of conducting opinion in a way beneficial to the public, and was trying to protect the profession in a manner that avoided the newspaper ownership and management exclusively interested in profit, but also, as a springboard to obtaining and influencing power, taking journalism away from the desired place of being a provider of information and spreader of ideas. It was a belief that moral honesty was the only possible way of running a good newspaper, that is, one trusted by the public.

We wanted directors who, instead of being merchants, would first be journalists, leading their companions into the battle of ideas, - which would not prevent them from being good administrators. Knowing how to conduct the loyal propaganda of opinion does not prevent them from being businessmen of merit. We have been saying it for a long time: regarding the subject of business, the greatest skill is honesty. ${ }^{41}$

Resuming and moving the debate forward by enforcing the position of equilibrium being passed on by the Congress, Victor Tauney, a French publicist and member of the Board of

\footnotetext{
38 «La plupart des rédacteurs ne sont pas indépendants. Ils ne sont que les employés et non les propriétaires de leur journal. Ils sont constamment à la merci d'un congédiement» (CONGRĖS, 1889, p.131).

39 «Et, de même que vous vous occupez de moraliser les journalistes, - et vous avez raison de les enseigner, de les former, - ils voudraient [Les journalistes de l'Association Française de la Presse Républicaine] - je vais dire quelque chose de bien gros - qu'on s'occupait de moraliser les directeurs. Ils voudraient que le directeur ne fût plus le vulgaire marchand de papier qui vend à une clientèle; que ce fût un véritable journaliste de profession, en ayant fait sa carrière ; et qu'on ne voie plus des marchands de charbon, parce qu'ils sont millionnaires, devenir des directeurs» (CONGRĖS, 1889, p.80).

40 «Je ne vois pas comment le Congrès ou le Comité pourraient empêcher qu'un marchand de charbon fonde un journal, prenne des rédacteurs et les paie. Je ne voie aucun moyen matériel et pratique de s'y opposer. Je suis copropriétaire du plus grand journal de Madrid IO Liberall, qui tire à 100.000 exemplaires. Je suis vice-président du Comité directeur et il y a trente-huit ans que je suis journaliste; j'ai donc une certaine expérience de la profession. Malgré cela, je le répète, je ne vois aucune arme possible contre l'invasion des marchands de charbon dans la direction des journaux. Il n'y a rien-là qui sorte des règles de la justice et du droit commun à chaque pays» (CONGRÉ, 1889, p. 83). 41 «On voudrait des directeurs qui, au lieu d'être des marchands, seraient les premiers de leurs journalistes, entraînant leurs compagnons à la lutte des idées, - ce qui ne les empêcherait pas d'être de bons administrateurs. Savoir conduire la propagande loyale des opinions n'empêche pas d'être un homme d'affaires émérite. Il y a longtemps qu'on la dit : en matière d'affaires, le suprême habilité est l'honnêteté» (CONGRĖS, 1889, p.80).
} 
the Union of the Press, demonstrated an ability to adapt and answer the democratic principle applied to how the organizational structure of journalism worked:

We all wish for the moral and material improvement of the profession. It is very easy to achieve this by entering the spirit of law and forming Employers' Associations, Editors' Associations and Mixed Associations. True journalists, the newspaper managers, just like us, have the same interest of being surrounded only by worthy confreres of the profession. It is a beautiful spectacle to see our Associations so aware of social peace during a troubled century. ${ }^{42}$

He also recognized the political importance of the organizational example of the press at an international level as far as issues representing the problem of growth in democratic and representative societies in the end of $19^{\text {th }}$ century were concerned, namely the social question as an aspect of the issue of equality through specialized education.

At this point, it is appropriate to introduce the next point under discussion in the Congress was and for which it became known and cited, by first making a bridge using the theme of journalistic identity concerning authorship and journalism within higher education ${ }^{43}$.

Since the mid-19 ${ }^{\text {th }}$ century, people had been witnessing a change in the quality of journalism on both sides of the Atlantic. With the social widening enabled by the continuous democratization of society, the Press of opinion was giving way, or cohabiting, with those newspapers which successfully prioritized information.

With the improvement of printing machines, with the telegraph and the telephone, with the transformation of the public spirit, always and evermore eager to be informed, a metamorphosis took place: debate was overshadowed by information [...] The day when this revolution is accomplished, notwithstanding those imbeciles who claim that we do not exercise a classifiable profession, is the day journalism becomes a career. ${ }^{44}$

Portugal followed this movement and, in 1865 , the newspaper Diário de Noticias (CUNHA, 2008, pp.53-83) was founded, corresponding to the model of the informative press, just like others which had already been published in France and in the United States (DELPORTE, 1999 ; FORDE \& FOSS, 2012; KAPLAN, 2002; SCHUDSON, 1978). Eduardo Coelho (1835-1889), owner of the daily newspaper, got the idea from the Parisian Petit Journal, directed by Moïse Millaud (1813-1871), where he had worked as a reporter. As we know it would be the Reporter who would play an important role in the change journalism. The presence of Reporters and their objective ways of telling the news as facts occurred, begin to give credibility to the daily news.

Like other publications all over the world, the circulation of the Portuguese newspaper grew exponentially because they coupled good information with the facts in context, framed within the causal reality that had led to the event. What is more, by not completely abdicating the editorial article, which was used only in important circumstances or when asking for social support for worthy causes brought to the attention of its readers, this space within the newspaper became more credible than ever.

Societies with representative parliamentary democracies experienced a free space for public opinion that had found its main vehicle in the press, and from there several representations of that opinion were also considered. According to a Portuguese journalist from the turn of the century, Alberto Bessa 45 , in his work of 1904, called, The Journalism, the newspaper was the creator of audiences and the waster of crowds, meaning

\footnotetext{
42 «Nous souhaitons tous l'épuration morale et l'amélioration matérielle de la profession. Il est très facile d'atteindre ce but en entrant dans l'esprit de la loi, et en formant des Associations de patrons, des Associations de rédacteurs et des Associations mixtes. Les vrais journalistes, directeurs de journaux, ont le même intérêt que nous à n'être entourés que des confrères dignes de la profession. C'est, dans un siècle troublé un beau spectacle que de voir nos Associations si soucieuses de la paix sociale» (CONGRĖS, 1889, pp. 80-81).

43 CONGRĖS, 1889, p.75-85

44 Paul Oeker and Albert Bataille state: «Avec le perfectionnement des machines d'imprimerie, avec le télégraphe et le téléphone, avec la transformation de l'esprit public, toujours et de plus en plus avide d'être informé, une métamorphose s'est opérée : la polémique a été reléguée au second plan, l'information est passée au premier [...] Le jour où cette révolution s'est accomplie, le journalisme, n'en déplaise qu'aux sots qui prétendent que nous n'exerçons pas une profession classée, le journalisme est devenu une carrière» (CONGRĖS, 1889, p.126).

45 Alberto Bessa (1861-1938) was a confessed reader of the philosopher Jean-Gabriel de Tarde (1843-1904), mainly of his work L'opinion et la foule (1901).
} 
that a new concept of public would replace with advantage the idea of unpredictable multitudes. Newspaper readers identified themselves and were identified in a kind of intellectual solidarity that only the press allowed, that is, each reader communed or belonged to different audiences, and the knowledge that he read the newspaper or a specific article that was read and followed by others created a feeling of a public whose members did not know each other but who trusted that existed, as long as the paper served as a mirror of its wills and tastes.

Indeed, the respect and trust between the newspaper and its readers supported a trait of communion that was daily updated. According to Bessa - and most contemporary authors since that was the period when the press began to think about itself and provide a historical and cultural vision of the role it had so far played - by promoting the so called progress from crowd to audience, the press was, at the same time, guiding and reflecting public opinion, it was democracy in action.

At this point I am in full agreement with the Brazilian publicist and jurist, Ruy Barbosa, who asserts that the newspaper should lead the wishes, the determinations and acts; it should reflect impressions, feelings, emotions; it should lead protests, complaints; it should reflect aggressions, injustices, sufferings; it should lead initiatives, movements, freedom, reflecting threats, oppression, tyranny. ${ }^{46}$

The press, journalism and journalists' relations with democracy have been documented since the American and French revolutions and the liberal fights for freedom of thought and opinion. The existence of a free press was assumed by journalists as the guarantor of democracy, the same way politicians saw democracy as the support for freedom secured by a state of law.

Both representations completed each other and felt interdependent through the fact of being socially constructed, by creating a cultural sphere that evolved throughout the $19^{\text {th }}$ century. In that process, journalism and politics did not exclude each other, but the development of the related industry of the press, the reflex of a certain cultural massification, the gradual professionalization of journalism and its consequent professional ethics, and the enlargement of the rules concerning distribution of prestige with the progressive highlighting of members of the press, in short, this whole scenario contributed to an autonomy that would allow a relative independence of the class, with regard to the possible need for conflicts with established powers.

As the Portuguese journalist Alberto Bramão ${ }^{47}$ said in a conference in 1899 about the organization and independence of journalists: it was necessary to find a balance between their moral mission (freedom of choice) and their practical interest (professional survival).

Just as with politics, the journalistic independence from the literary milieu was also taking place, though society and even journalist associations were still formed by intellectual elite, the truth was that the literary and the journalistic style began to have well-defined spaces within newspapers. The reportages and the called serious information, in all its forms, from the literary chronicle to art reviews, from the courts and parliament sessions to the everyday events, were henceforward considered to be the responsibility of the professional press.

For this entire picture to become real, it meant journalism being considered a professional career and not a mere craft (BARRERA, 2012). The existence of higher education for those young people, who wished to be journalists, would be the culmination of this pursuit by the profession, which had started decades before (LIMA \& CARDOSO FILHO, 2012; LIPMANN, 2010; DEWEY, 2008).

Lisbon was where the international members of the press approved a program of studies attached to a report that committed all associations to taking this project forward. The discussion whether these courses were needed or not would continue (FREIRE, 1935; SOUSA, 2009; FRÖLICH \& HOLTZ

46 "Neste ponto estou de pleno acordo com aquele publicista e jurisconsulto (Ruy Barbosa) que assevera dever o jornal dirigir a vontade, a resolução e os actos; reflectir a impressão, o sentimento, as emoções; dirigir o protesto, a reclamação, a queixa; reflectir a agressão, a injustiça, o sofrimento; dirigir a iniciativa, o movimento, a liberdade; reflectir a ameaça, a opressão, a tirania" (BESSA, 1904, p.35)

47 Alberto Bramão (1865-1944), O Jornalismo, Conferência na AJL, Lisboa, 1899 
BACHA, 2003), but the cutting edge of journalism meeting in Lisbon decided that it was important to commit to the goal of creating in each country a college degree in journalism. To reinforce this idea a letter emerged which was read at the Congress from the director of the well-known French paper, Figaro, Antonin Périvier, supporting the idea and offering to receive trainees from the future course that he would help finance ${ }^{48}$.

The work was presented to the Congress by Paul Oeker, from San Francisco, and Albert Bataille from Paris ${ }^{49}$. It reflected the recent history of teaching journalism pointing out German and North American examples, improving the course of J. French Johnson from the Pennsylvania University, Philadelphia (1893), and his program that consisted of a more general and theoretical part, followed by a second more practical and professionalized part.

The present moment is a really opportune one for this effect; as within letters there exists a spirit of great liberality and we can see the establishing of periodical publications that seek to present their readers with the best of modern thinking, beyond the limits of only one state or only one nationality. ${ }^{50}$

In defense of youth and as a guarantee for the future of journalism, the announced teaching program was admitted as capable of influencing the world for the pursuit of good and presented as an indication of the intentions of all the hitherto international press congresses. More important, the mentioned program showed the effort of creating as much consensus as possible between the ideas of journalism as a theoretically teachable profession or a craft that one learns only by working, to the point of allowing the unanimous approbation of the participants of Lisbon Congress.

\section{CONCLUSION}

The importance of the international Congress of Lisbon can only be read in the light of its cultural and political framework on both sides of the Atlantic. In trying to make sense of a cultural and political history of the press, it has to be accepted that this was naturally one involving advances and setbacks that requires understanding, while running the risk of dealing only with the advances and as such making history up and narrating a fiction.

Thus, the context of influences much wider than the event itself has been described to allow a better understanding. As with those involved, one is aware of the importance it obtained as another step forward in the lofty mission that journalists and the public attributed to the role of the press, as well as the validity of its dissemination describing a particularly decisive period in the evolution of democratic society. The event showed, in a clear way, that as far the press was concern all the countries involved had the same problems and goals. Also showed, that when the way to solve the first or to obtain the second were divergent, solutions could be found within the differences.

The newspapers of the middle of the 19th century had already translated the demands for information that was beginning to bear the mark of journalistic truth in a moral sense, that is, not only as objectivity but also as honesty, especially in line with the political analysis and commentary arising from events of public interest as a recognized journalistic practice. This constant identification communicated from the reader to the newspaper and vice-versa would be the key to the success of the Reportage style that was beginning to impose itself, and to which the national and large circulation newspapers corresponded, and which would transform information into a lucrative industry, as we saw earlier as a Lisbon Congress debate.

The awarding of performance-based merit to the profession which was developed at the end of that century would become a key element in social construction. In this sense the transformation of the role of the intellectual and the elite thus

\footnotetext{
48 Joseph Pulitzer did the same thing in 1903 offering his newspaper for trainees and supporting a higher education course of journalism (ROBERTS \& FOSS, 2012).

49 CONGRĖS, 1889, p. 126-136.

50 «Le moment présent est tout à fait opportun à cet effet, puisqu'un esprit de large libéralité internationale règne dans les lettres, et nous voyons même se fonder des publications périodiques qui se proposent de présenter à leurs lecteurs la fleur de la pensée moderne. sans la chercher dans les limites d'un seul État ou d'une seule nationalité» (CONGRĖS, 1889, p.116).
} 
represented at the turn of the 19th to the 20th centuries, journalists included, endowed itself with the conviction that it could and should intermediate between people and power and that in that regard they had a duty to fulfill. The historians of the dayby-day ${ }^{51}$, with varied social backgrounds and their consequent professionalization, went on to earn their space and credibility.

From 1894 the creation of an international press association led to both internal and external consequences on several fronts. The wide-ranging professional associations joined the International Union of the Press Associations, and once statutorily accepted, that is, devoted to the defense of the press and its members and not dependent on governmental pressures, were supposed to form a kind of confederation, the operation of which was intended to be democratic to the rest of the world in an exemplary manner.

The tens of thousands of journalists enrolled through National Associations and the official logistical support to the various international congresses demonstrated the importance given to the entity that possessed and distributed information. The assignment of accreditations to correspondents all over the world was another matter testifying to the importance of the International Union and its representative nature culminated in the fact that its Central Bureau had been legitimized by its peers as an international court of arbitration for international ethical conflicts within the press.

The independence of the press, as a profitable industry, regarding the political institution was also accompanied in this sense by journalist organization in relation to their former companions within the literary world. This was, however, carried out, in terms of principles involving the absence of class distinction or the privilege of birth related to the idea of the Republic of letters which had maintained affinities and led to the composition of the intellectual Vanguards.

As a symptom of growth and adaptation, the debate during the Congress crisscrossed several important positions regarding the evolution of journalism, both as an idea and a concept, and as a profession, that shows the complementarity between moral and material improvements.

This debate revealed certain views on journalism, some more and others less militant, or informative or confrontational, and raised issues still being updated even in the present day. Labor issues and established hierarchies based not on knowledge or experience within the profession but on economic power and, as a consequence, the existent dilemma between the independence and the freedom of the professionals of the press and their need for economic survival allied to the need for the recognition of the profession by the public as a useful and hopefully successful career.

The congresses and their theoretical work provided an important contribution to the exposure and the deepening of those issues that in the Lisbon Congress led to the approval of a directive by which each national associations should promote journalism within higher education, as experiences already carried out on both sides of the Atlantic were presented in a cumulative and comparative way.

The awareness of the importance which had been assumed by the press, as shown by its own agents, allied both to a concern for promoting the best way of making information circulate or to respect for the ethical and moral codes of their democratic example as set before the public and particularly before youth, to enable them to embrace their talent in not only a dignified manner but also and above all as a career profession, emphasized well the timeliness of the contribution provided by international journalism reunited in Lisbon in 1898.

\section{REFERENCES}

BESSA, Alberto. O Jornalismo, Lisboa: Viúva Tavares Cardoso, 1904.

BRAMÃO, Alberto. O Jornalismo, Conferência na AJL. Lisbon: 1899.

BARRERA, Carlos. Transatlantic views on journalism education before and after world war two: two separate worlds? Journalism Studies, Routledge, v. 13, n. 4, p. 534-549 2012. https://doi.org/10.1080/1461670X.2011.637722. 
BJORK, Ulf Jonas. Scrupulous integrity and moderation: the first international organization for journalists and the promotion of professional behavior, 1894-1914. American Journalism, Athens, v. 22, n. 1, p. 95-112, 2005. https:// doi.org/10.1080/08821127.2005.10677625.

BUREAU Central des Associations de Presse. Liste des Journalistes inscrits au «Bureau des correspondants», Milan: Impr. del Corriere della Sera, 1898.

CONGRĖS International de la Presse. Compte rendu des travaux du 5éme Congrès International de la Presse. Lisbonne, Bordeaux: Imprimerie G. Gounouilhou, 1899.

CUNHA, Alfredo. Diário de Notícias. A sua fundação e os seus fundadores. Lisboa: Tipografia universal, 1925.

DELPORTE, Christian. Les journalistes en France (18801950): naissance et construction d'une profession. Paris: Seuil, 1999.

DEWEY, John. Democracy and education: an introduction to the philosophy of education, The original classic edition. Queensland: Emereo Publishing, 2008.

FEYEL, Gilles. Aux origines de l'identité professionnelle des journalistes : les congrès internationaux des associations de la presse (1894-1914), in L'Identité professionnelle des journalistes, dir. Michel Mathien et Rémy Rieffel, Strasbourg CUEJ, 1995. p. 139-162.

FORDE, Kathy Roberts; FOSS, Katherine. The facts - The color! - The facts. Book History, [s. l.], v. 15, p. 123/151. 2012. https://doi.org/10.1353/bh.2012.0003.

FREIRE, João Paulo (Mário). Escolas de Jornalismo. Porto: Editora Educação Nacional, 1935. p. 51.

FRÖHLICH, Romy; HOLTZ-BACHA, Christina, ed., Journalism educations in Europe and North America: an international comparison, Hampton Press, 2003. Part II, p. 93-135.

HAMELINK, Cee. The politics of the world communications. New Jersey: Wiley-Blackwell, 2011.

KAPLAN, Richard. The rise of objectivity, 1865-1920. Cambridge: Cambridge University Press, 2002.

KUBKA, Jiri; NORDENSTHENG, Kaarle. Useful Recollections: excursion into the history of the International Movement of Journalists. Prague: International Organization of Journalists, 1986

LIMA, Marcus António Assis; CARDOSO FILHO, Jorge. Jornalismo, Democracia e Educação, Intercom RBCC, São Paulo, v. 35, n. 2, jul./dez. p. 39-60, 2012. https:// doi.org/10.1590/S1809-58442012000200003.

LIPPMANN, Walter, Liberty and the news. New York: Dover Publications, 2010.

MIRANDA, Paula Cristina Galvão Mateus. O Jornalismo em Portugal: elementos para uma arqueologia de uma profissão (1865-1925). 2005. 2 v. Tese (Doutorado) - Curso de História, Universidade de Évora, Évora, 2005.

MIRANDA, Paula Cristina Galvão Mateus. De politicos e escritores a jornalistas: jogos de identidade (1865-1925). Lisbon: Chiado Editora, 2014.
SCHUDSON, Michael. Discovery the News: a social history of American newspapers. New York: Basic Books, 1978.

SINDICATO Nazionale fascista dei giornalisti; FEDERAZIONE nazionale della stampa italiana. Statuto dell'ufficio Centrale delle Associazoni di Stampa, Annuario della Stampa Italiana. Roma: Bureau Central des Associations de Presse Federazione Internazionale 1897. p. 500/50.

SOUSA, Jorge Pedro. A discussão sobre a introdução do ensino superior do jornalismo em Portugal. Verso e Reverso, [s. l.], ano XXIII, n. 54, 2009/3. https://doi. org/10.4013/ver.2009.23.54.02.

SOUSA, Jorge Pedro. Eduardo Coelho, um inovador no jornalismo português oitocentista - o caso do Diário de Notícias. In: CABRERA, A. (org.). Jornais, Jornalismo e Jornalistas (séculos XIX-XX), Lisboa: livros horizontes, 2008. p. 53-83.

\section{Adelaide Maria Muralha Vieira Machado}

Pós-Doutoranda FAPESP na Universidade de São Paulo.

\section{Mailing address}

Adelaide Maria Muralha Vieira Machado

Universidade de São Paulo

Rua do Lago, 717

Butantã 05508-080

São Paulo, SP, Brasil 